\title{
SOCIAL MAPPING TINGKAT LITERASI INFORMASI MASYARAKAT DESA PASEBAN, KECAMATAN KENCONG, KABUPATEN JEMBER
}

\author{
Tjahjanulin Domai $^{1}$ ), Ratih Nur Pratiwi ${ }^{2)}$, Niken Lastiti V.A ${ }^{3)}$, Anita Tri Widiyawati ${ }^{4)}$ \\ Universitas Brawijaya, Jalan Veteran Malang \\ 1) email: anitatriwidiyawati@ymail.com
}

\begin{abstract}
ABSTRAK
Information literacy includes a person's knowledge relating to information needs and the ability to identify, locate, evaluate, process, and create and use information to solve existing problems effectively. The type of research used is survey research with qualitative approach. The result of research indicate that based on IDM value, Paseban Village is classified as developing village with value 0,603 . The information literacy level of Paseban villagers is still moderate, that is $62,25 \%$ of people understand information access, information evaluation is $52,875 \%$ and information usage is $40,87 \%$. Potential Paseban village is quite diverse ranging from agriculture, livestock and tourism. Suggested recommendation is Improvement of information literacy of Paseban villagers through training and development of information center that provides access to information for the community. Meanwhile, based on data on village potential and IDM indicator, several recommendations are improvement of water drainage to Sadar times, normalization of irrigation channels, provision of public toilets for coastal areas, agricultural training and tool assistance, greening of mangrov, training of SMEs, establishing cooperatives for fishermen and farmers and improvements village Road.
\end{abstract}

Keywords: Literasi informasi, pemetaan.

\section{PENDAHULUAN}

Di era globalisasi informasi sudah menjadi kebutuhan pokok bagi kehidupan manusia. Holland dalam Sulistyo-Basuki (1992:87) menjelaskan bahwa informasi memiliki arti yang diungkapkan oleh manusia atau ekstrak dari fakta, representasi fakta, dan sama dengan cara konvensi yang diketahui dari representasi yang digunakan. Salah satu cara untuk memperoleh informasi yaitu dengan membaca, baik membaca buku, koran, ataupun artikel. Menurut Marahimin dalam Rahmawati dan Blasius (2012:25) membaca merupakan kegiatan yang paling penting dalam kehidupan manusia dan dapat dikatakan bahwa semua proses belajar didasarkan pada kemampuan membaca. Melalui membaca masyarakat menciptakan ideide baru, mendapatkan informasi, dan menambah ilmu pengetahuan sehingga wawasannya menjadi luas dan berkembang. Sejarah kehidupan manusia sudah mulai berkembang dengan adanya kemajuan peradaban contohnya perkembangan naskah tulisan, penemuan bahan untuk membuat kertas, dan dilanjutkan dengan penemuan mesin cetak. Baswedan (2014:22) dalam Badan Pusat Statistik (BPS) tahun 2013 menyampaikan, orang membaca di Indonesia hanya 20 persen. Sementara hampir 80 persen orang lebih suka nonton TV (televisi) dan mendengarkan radio. Berbeda dengan beberapa negara maju di dunia seperti di Amerika Serikat, wajib baca buku setiap sekolah 30 buku, 
di Indonesia 0 persen. Sedangkan pada data UNESCO pada tahun 2012 Baswedan mengatakan, indeks minat baca Indonesia baru mencapai 0,0001 . Artinya, dalam setiap 1.000 orang Indonesia, hanya ada satu yang mempunyai minat baca.

Kebiasaan membaca dapat diperkenalkan orang tua sebagai orang terdekat sejak dini, ataupun guru di sekolah. Orang tua maupun guru di sekolah tersebut tidak hanya mendorong anak-anaknya tetapi juga mencontohkan kebiasaan membaca. Sutarno (2006:30) mengungkapkan beberapa faktor yang mampu mendorong bangkitnya minat baca masyarakat: Pertama, rasa ingin tahu yang tinggi atas fakta, teori, prinsip, pengetahuan, dan infomasi. Kedua, keadaan lingkungan fisik yang memadai, dalam arti tersedianya bahan bacaan yang menarik, berkualitas, dan beragam. Ketiga, keadaan lingkungan sosial yang lebih kondusif. Keempat, rasa haus informasi, rasa ingin tahu, terutama yang aktual. Kelima, berprinsip hidup membaca merupakan kebutuhan rohani.

Salah satu upaya dalam pengembangan minat baca masyarakat dalam kaitannya dengan pengembangan pendidikan adalah melalui pembentukan dan pengembangan perpustakaan berbasis komunitas atau yang sering dikenal dengan istilah Taman Bacaan Masyarakat (TBM). Program pendirian TBM yang merupakan salah satu program pemerintah mengacu pada Undang-Undang Republik Indonesia Nomor 20 tahun 2003 tentang Sistem Pendidikan Nasional, pasal 26 ayat (4) tercantum bahwa satuan pendidikan nonformal terdiri atas lembaga kursus, lembaga pelatihan, kelompok belajar, pusat kegiatan belajar masyarakat, majelis taklim, serta satuan pendidikan yang sejenis. Keberadaan dan eksistensi mendirikan TBM diharapkan sebagai perpustakaan yang dekat dengan masyarakat karena sasaran utamanya adalah warga masyarakat, terutama di daerah yang sulit dijangkau oleh perpustakaan umum (Perpustakaan kota maupun daerah).

Keberadaan TBM ini ditengah masyarakat diharapkan mampu meningkatkan minat dan lebih dari itu TBM juga mampu berfungsi sebagai salah satu upaya dalam melakukan kegiatan belajar serta memenuhi kebutuhan pendidikan dalam masyarakat melalui program-program literasi informasi. Mengingat diera informasi, perkembangan ilmu pengetahuan dan informasi semakin pesat sehingga sering memunculkan permasalahan dalam pengelolaan informasi dari mulai pencarian, penemuan dan pemanfaatan informasi. Literasi informasi yaitu kemampuan mengidentifikasi, menemukan, mengevaluasi, dan menggunakan informasi yang terutama dari sumber elektronik untuk membatasi atau mengatasi masalah, baik untuk kepentingan pribadi, sosial, budaya, maupun bisnis.

Dalam literalur lain, Literasi informasi merupakan kemampuan untuk mencari, mengelola, mengevaluasi, dan menggunakan informasi (Mortimer, 2007). Tidak hanya itu, literasi informasi juga dikaitkan dengan kemampuan seseorang untuk mengkomunikasikan informasi yang mereka peroleh kepada orang lain. Dari pengertian tersebut, literasi informasi tidak hanya terbatas pada proses penelusuran untuk mendapatkan informasi yang mereka butuhkan, tetapi juga berkaitan dengan kemampuan seseorang untuk memanfaatkan informasi tersebut dengan baik dan benar sehingga mampu digunakan dalam pemecahan masalah yang sedang dihadapi. Diharapakan TBM menjadi tempat bagi masyarakat dengan berbagai macam program dan pelayanan di dalamnya yang mampu memotivasi dan menumbuhkan minat belajar, minat baca, peningkata literasi informasi masyarakat serta mengembangkan bakat 
masyarakat sesuai dengan potensi yang ada.

Keberadaan perpustakaan komunitas merupakan bagian integral yang mendukung proses pengembangan msayarakat informasi. Keberadaan perpustakaan komunitas yang representatif dalam jangka panjang dimaksudkan untuk:

A. Menumbuhkembangkan minat baca tulis masyarakat

Masyarakat dapat memanfaatkan waktu untuk mendapat informasi di perpustakaan. Kebiasaan ini meningkatkan minat baca mereka. Kemudian dari banyak membaca dan kualitas bacaan yang pada akhirnya dapat menumbuhkan minat tulis.

B. Mengenalkan teknologi informasi

Perkembangan teknologi informasi harus terus diikuti oleh para pengelola perpustakaan komunitas. Untuk itu, perlu proses pengenalan dan penerapan teknologi informasi dari perpustakaan yang disesuaikan dengan kebutuhan masyarakat setempat

C. Membiasakan akses informasi secara mandiri

Masyarakat perlu didorong dan diarahkan untuk memiliki rasa percaya diri dan mandiri untuk mengakses informasi. Hanya orang yang percaya diri dan mandirilah yang mampu mencapai kemajuan.

D. Memupuk bakat dan minat

Bacaan, tayangan gambar, dan musik di perpustakaan mampu menumbuhkan bakat dan minat seseorang. Melalui kegiata yang variatif dalam layanan perpustakaan komunitas (TBM) akan memotivasi masyarakat untuk menemukan dan mengembangkan bakat dan potensi yang ada.

Untuk mendapat kemampuan ini seseorang perlu mendapat pendidikan dan bimbingan terlebih dahulu.Pendidikan literasi informasi hendaknya diperkenalkan sejak dini agar seorang nantinya terbiasa dengan pencarian informasi yang dibutuhkan sehari-hari terutama dalam bidang akademik. Kemampuan literasi semacam ini bersifat longlife learning atau dengan kata lainpembelajaran yang berguna sepanjang hayat. Kemampuan ini dapat dipakai dalamkehidupan mereka kelak misal dalam kehidupan sosial, bidang pekerjaan, atau dalam mengambil keputusan.

Letak dan keadaan geografis mitra. Kecamatan Kencong terletak pada sisi barat daya Kabupaten Jember. Wilayahnya berada kurang lebih $45 \mathrm{Km}$ arah barat dari ibukota Kabupaten Jember yang merupakan daerah dataran rendah dengan ketinggian $9 \mathrm{~m}$ di atas permukaan laut. Laut ini merupakan daerah pantai dengan pemandangan pantainya yang sangat indah, yaitu Pantai Paseban. Di sisi wilayah Kecamatan Kencong dibatasi beberapa kecamatan. Di sebelah barat berbatasan dengan Kabupaten Lumajang. Di sebelah selatan berbatasan langsung dengan Samudera Indonesia. Di sebelah timur berbatasan dengan Kecamatan Gumukmas. Di sebelah utara berbatasan dengan Kecamatan Jombang dan Umbulsari. Kecamatan Kencong memiliki luas wilayah 5.865,3 hektar. Secara administrasi terdiri atas lima desa, 24 dusun/perdukuhan, 117 rukun warga, dan 561 rukun tetangga. Lima desa ini, terdiri atas: Desa Paseban, Desa Cakru, Desa Keraton, Desa Wonorejo, dan Desa Kencong.

Luas wilayah Desa Paseban adalah 7,99 $\mathrm{Km}^{2}$ dan jarak Kantor Desa Paseban ke Kantor Kecamatan Kencong adalah 10 $\mathrm{Km}$. Luas wilayah desa dan penggunaan lahan sebagai berikut: pemukiman 8,7 ha, pertanian sawah 356 ha ladang/tegalan 109 ha, untuk bangunan 5,62 ha, perikanan darat/air tawar 2,75 ha, dan kuburan 1,5 ha. Desa Paseban terdiri atas empat (4) dusun/perdukuhan, 12 rukun warga, dan 52 rukun tetangga. Empat dusun/pedukuhan tersebut, terdiri atas: Dusun/Pedukuhan Dusun/Pedukuhan Sidomulyo, dan 
Dusun/Pedukuhan Bulurejo. Batas-batas wilayah Desa Paseban, terdiri atas: sebelah utara adalah Desa Cakru, Kecamatan Kencong; sebelah selatan adalah Samudera Indonesia; sebelah barat adalah Desa Wot Galih, Kecamatan Yosowilangun; dan sebelah Timur adalah Desa Kepanjen, Kecamatan Gumukmas. Orbitasi Desa Paseban, antara lain: jarak ke ibukota kecamatan terdekat (Kecamatan Kencong) adalah $7 \mathrm{Km}$, dan lama tempuh jarak ke ibukota kabupaten/kota (Kabupaten/Kota Jember) terdekat adalah 2 jam.

Desa Paseban merupakan salah satu desa yang mempunyai potensi tinggi di Kabupaten Jember. Wilayahnya yang dekat dengat pantai merupakan kelebihan tersendiri yang dapat dijadikan sebagai sumber destinasi wisata dan juga sebagai sumber produksi ikan laut. Selain itu, pada dasarnya Desa Paseban mempunyai potensi yang sangat tinggi di bidang pertanian/sawah, ladang/tegalan, serta perikanan darat/tawar. Di bidang pertanian/sawah dan ladang/tegalan, masyarakat menanam berbagai jenis tanaman yang bervariasi, dari mulai polowijo sampai buah, bahkan umbiumbian. Sedangkan dari bidang perikanan, untuk perikanan air tawar banyak masyarakat yang membuat tambak-tambak, baik tambak di rumah maupun tambak yang dibangun di area dekat persawahan. Adapun produk perikanan air tawar, antara lain: gurami, lele, mujair, dan banyak lagi. Terdapat pula potensi perikanan air payau.

Berdasarkan potensi tersebut seharusnya masyarakat Desa Paseban bisa memanfaatkan potensi yang dimiliki untuk kemakmuran masyarakat itu sendiri, khususnya dari segi ekonomi. Akan tetapi, pada kenyataannya banyak dari masyarakat Desa Paseban dari pemudanya, ibu rumah tangga, kepala keluarga lebih memilih meninggalkan desa dan merantau untuk menjadi TKI ataupun bekerja di wilayah lain. Masyarakat beralasan bahwa di desa tidak ada yang dapat dihasilkan. Adapun negara sasaran dari masyarakat menjadi TKI adalah Malaysia dan Arab Saudi, sedangkan wilayah di Indonesia yang menjadi sasaran dari masyarakat Desa Paseban untuk bekerja adalah: Kalimantan, Sumatera, Bali, dan Papua. Karena masyarakat Desa Paseban tidak mempunyai kemampuan yang dapat diandalkan, kebanyakan dari mereka menjadi buruh kasar.

Mayoritas masyarakat Desa Paseban tidak mempunyai literasi informasi yang baik bahkan ada beberapa orang yang masih buta huruf, sehingga mereka tidak dapat memaksimalkan potensi yang dimiliki dalam pemenuhan kebutuhan sehari-hari. Kurangnya pengetahuan dan informasi bagaimana menjadikan potensi yang dimiliki mempunyai nilai lebih yang dapat menghasilkan pemasukan ekonomi bahkan bagaimana mendistribusikan produk yang dihasilkan kepada tengkulak yang tepat menjadi kendala tersendiri. Sehingga jika dilihat dari keadaan situasi di Desa Paseban, maka masyarakat Desa Paseban sangat membutuhkan kemampuan literasi informasi dan perpustakaan komunitas desa yang sekaligus menjadi pusat informasi bagi masyarakat Desa Paseban untuk memaksimalkan potensi yang dimiliki demi kesejahteraan masyarakat itu sendiri. Pelatihan mengenai literasi informasi dengan menyadari adanya potensi local content daerah serta sarana untuk mengembangkan kemampuan literasi itu sendiri dengan adanya Taman Baca Masyarakat (sekaligus sebagai pusat informasi) merupakan tujuan akhir dari pelaksanaan pengabdian ini.

Untuk langkah pertama dilakukan pemberdayaan bidang informasi (peningkatan minat baca dan literasi informasi melalui optimalisasi peran perpustakaan komunitas/TBM), maka dibutuhkan adanya social mapping mengenai tingkat literasi informasi masyarakat serta social mapping mengenai kebutuhan informasi 
masyarakat dengan berdasar pada potensi local content yang dimiliki oleh masyarakat Desa Paseban, Kecamatan Kencong, Kabupaten Jember. Diharapkan dengan adanya mapping tingkat literasi informasi masyaraka, pemanfaatan potensi di Desa Paseban menjadi lebih optimal. Berdasarkan latarbelakang di atas maka rumusan masalah yang diangkat dalam papwer ini adalah:

1) Bagaimanakah posisi Desa Paseban berdasarkan nilai Indeks Desa Membangun?

2) Bagaimanakah pemetaan literasi informasi masyarakat Desa Paseban, kecamatan Kencong Kabupaten Jember?

\section{METODE}

Jenis penelitian yang digunakan dalam penelitian ini adalah penelitian survey dengan pendakatan kualitatif. Penelitian ini menekankan pada menganalisis dan menggambarkan secara rinci, jelas, dan cermat tentang objek yang diteliti dan kondisinya

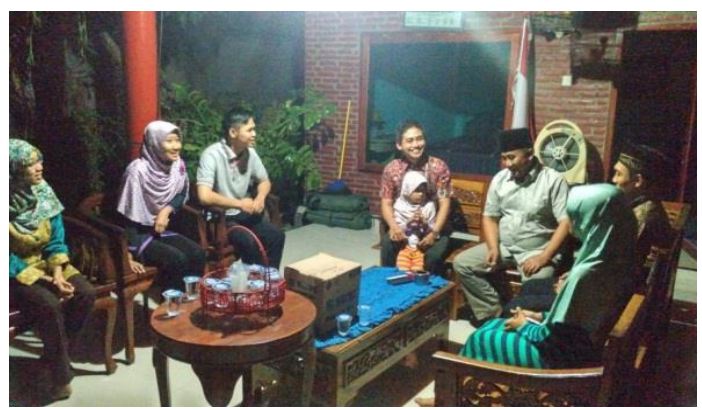

Gambar 1. Pelaksanaan Focus Group Discussion (FGD) internal (FGD Tahap 1) dengan melibatkan Kepala Desadan Sekretaris Desa Paseban, Kecamatan Kencong, Kabupaten Jember (doc. Pribadi, 2017)
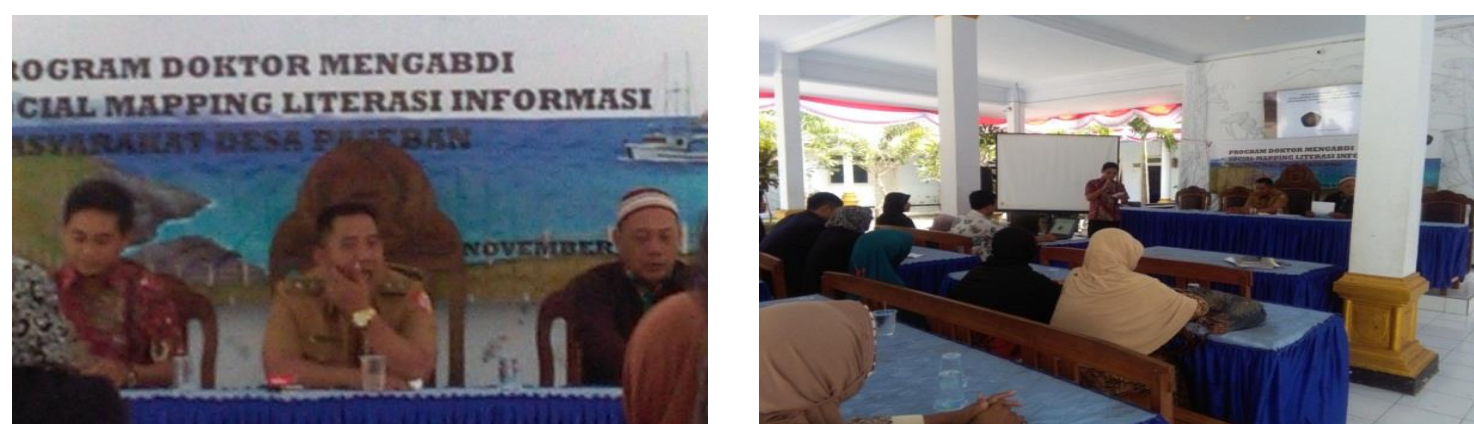

Gambar 2. Kegiatan: Pelaksanaan sosialisasi literasi informasi dan Focus Group Discussion (FGD) Terbuka (FGD Tahap 2) dengan melibatkan Perangkat Desa serta diambil oleh peneliti meliputi:

A. Hasil Indeks Desa Membangun

B. Pemetaan literasi informasi masyarakat desa Paseban:

1) Akses

2) Evaluasi

3) Penggunaan

Adapun standar literasi informasi yang digunakan untuk mengetahui tingkat literasi informasi masyarakat Desa Paseban adalan standar literasi inforasi yang dirumuskan oleh International Federation of Library Association and Institutions (IFLA). Pedoman internasional yang dibuat oleh IFLA mengenai literasi informasi bertujuan untuk menyediakan suatu kerangka kerja yang bertujuan untuk menyediakan suatu kerangka kerja yang bermanfaat bagi para profesional dalam rangka mengembangkan literasi informasi. Selain itu, pedoman literasi informasi IFLA merupakan suatu kerangka sistematika yang dibuat dengan berbagai kontribusi dari para profesional di bidang informasi serta hasil dari diskusi terbuka di Buenos Aires.

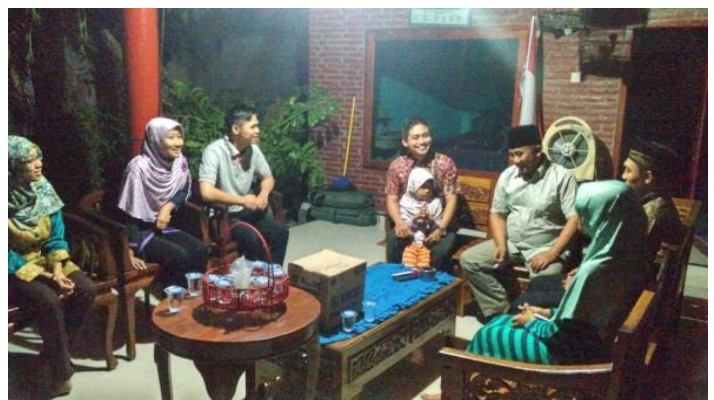




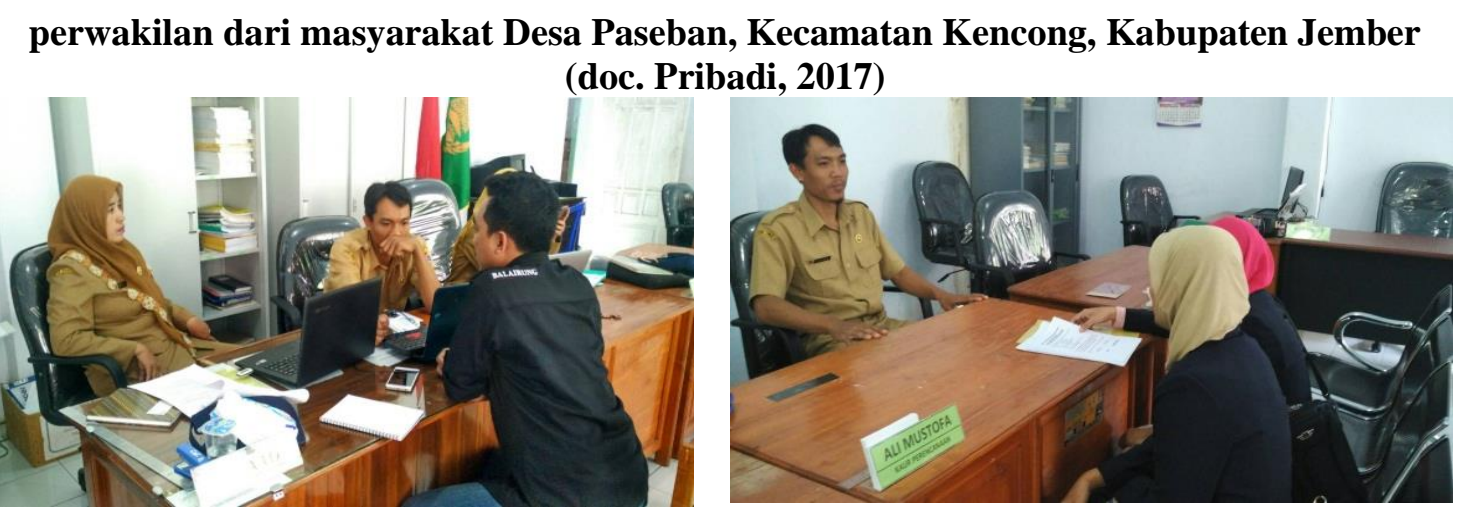

Gambar 3. Kegiatan: Pelaksanaan Focus Group Discussion (FGD) internal (FGD Tahap 3) dengan melibatkan Perangkat Desa Paseban, Kecamatan Kencong, Kabupaten Jember (doc. Pribadi, 2017)
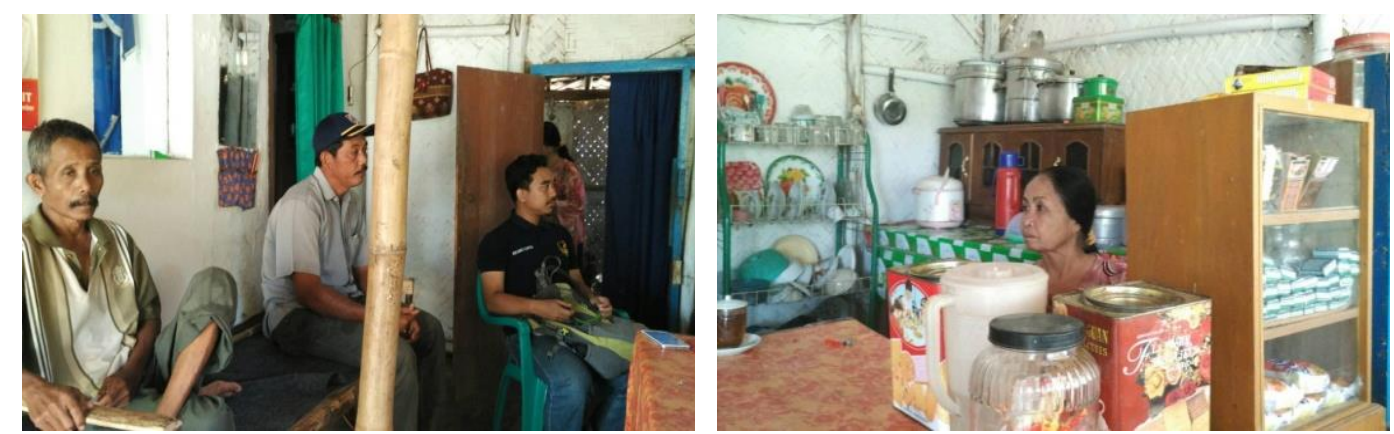

Gambar 4. Observasi dan wawancara langsung kepada masyarakat (langsung terjun oleh mahasiswa/enumerator) yang didampingi oleh petugas lapangan (doc. Pribadi, 2017)

Pedoman literasi informasi IFLA mencakup konsep literasi informasi dan standar kompetensi internasional yang dapat digunakan untuk mengetahui literasi informasi individu secara umum.Pedoman yang dibuat oleh IFLA dapat diadaptasi dan disesuaikan dengan kebutuhan lembaga yang bersangkutan.proses analisis data yaitu: (1) working with data, (2) organizing it, (3) breaking it into manageable units, (4) synthesizing it, (5) searching for patterns, (6) discovering what is important and what is to be learned, dan (7) deciding what you will tell others.

\section{HASIL DAN PEMBAHASAN}

A. Hasil IDM Desa Paseban

Desa Paseban adalah salahsatu desa

di Kecamatan Kencong, Kabupaten Jember yang memiliki penduduk berjumlah 8407.Desa ini terdiri dari empat dusun yaitu Bulerejo, Paseban, Balekambang, dan Sidumulyo. Berikut ini adalah hasil index desa membangun dari Desa Paseban.

Berdasarkan hasil penelitianan, maka nilai masing-masing indicator IDM Desa Paseban adalah sebagai berikut:

1) Bidang Sosial
a) $\operatorname{Kesehatan}(1-5)=0,76$
b) Pendidikan (6-12) $=0,6$
c) Modal social (13-26) $=0,69$
d) Pemukiman (27-34) $=0,8$

Jadi nilai untuk bidang sosial adalah

$0,76+0,6+0,69+0,8 / 4=0,71$

2) Bidang Ketahanan Ekonomi (35-46) $=32 / 60=0,53$

3) Bidang Ekologi $(47-52)=0,57$

$$
\begin{aligned}
\mathrm{IDM} & =1 / 3(0,71+0,53+0,57) \\
& =1,81 / 3=0,603
\end{aligned}
$$

Dari klasifikasi desa berdasarkan nilai IDM, maka desa Paseban tergolong sebagai desa berkembang.

Berdasarkan hasil observasi di lapangan, maka permasalahan yang ada di desa Paseban adalah sebagai berikut: 


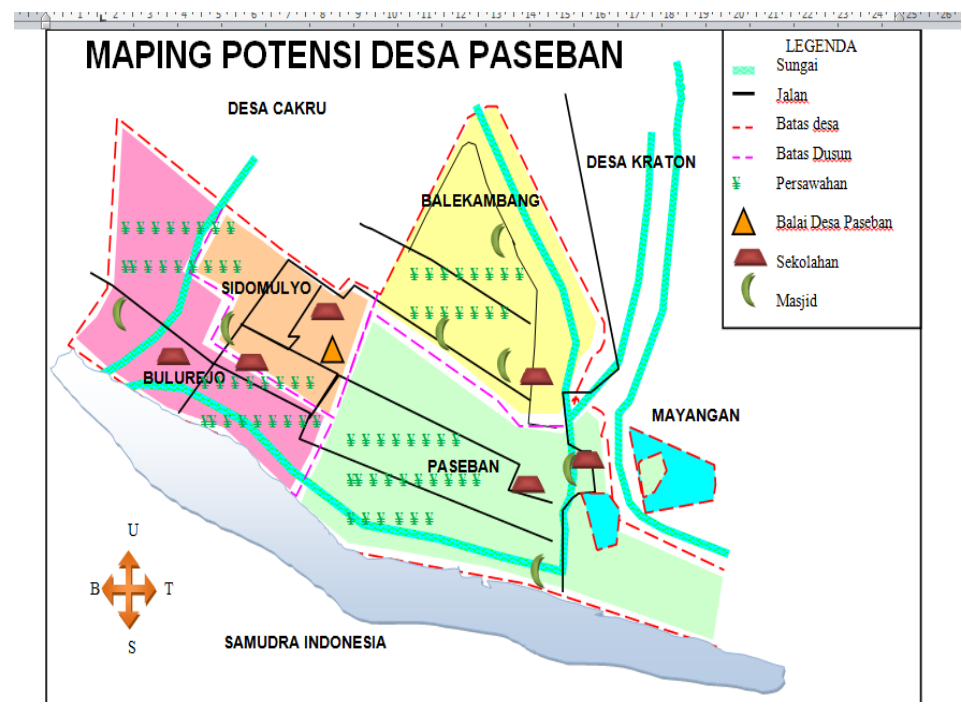

Gambar 5. Hasil Mapping Potensi Desa Paseban (doc. Pribadi, 2017)

1) akses jalan kurang baik, proporsi jalan masih makadam, perlu adanya perbaikan jalan.

2) masyarakat usia produktif lebih memilih merantau karena kurang adanya motivasi terkait pemberdayaan pemuda yang berdampak pada proses pembangunan desa.

3) penyakit yang sering dikeluhkan oleh masyarakat adalah lambung.

4) tingkat pendidikan terbanyak adalah lulusan SMP.

5) potensi pariwisata yang kurang diperhatikan, terlihat akses jalan yang kurang baik, sampah di sekitar pantai yang banyak, hingga tindakan reboisasi yang kurang.

6) nelayan tidak memiliki profesi sampingan yang melaut tergantung kondisi alam, hal tersebut ditambah kepemilikan berstatus lahan garap harus disewakan dan kurang adanya bimbingan terkait pemberdayaan potensi alam.

7) banyak ditemukan keong laut yang bisa dimanfaatkan dalam bentuk UKM, dengan isi keong diolah menjadi makanan ringan maupun makanan untuk ternak menthok, serta cangkang keong yang bisa didaur ulang dijadikan sovenir pariwisata.
8) pencemaran udara akibat aktivitas pabrik ikan

9) nelayan tidak memiliki profesi sampingan yang melaut tergantung kondisi alam, hal tersebut ditambah kepemilikan berstatus lahan garap harus disewakan dan kurang adanya bimbingan terkait pemberdayaan potensi alam.

10) terdapat masyarakat yang belum memiliki jamban pribadi.

B. Pemetaan Literasi Informasi Masyarakat Desa Paseban

Pemetaan literasi informasi yang dilakukan di Desa Paseban Kecamatan Kencong, Kabupaten Jember meliputi empat dusun (Dusun Sidomulyo, Dusun Bulurejo, Dusun Paseban, dan Dusun Balekambang) di Desa Paseban tanpa melihat batasan usia. Berdasarkan observasi yang telah dilakukan didapatkan data terkait aktivitas berbasis literasi informasi. Standar literasi informasi yang digunakan untuk mengetahui tingkat literasi informasi masyarakat Desa Paseban adalan standar literasi inforasi yang dirumuskan oleh International Federation of Library Association and Institutions (IFLA). Pedoman internasional yang dibuat oleh IFLA yang bertujuan untuk menyediakan suatu kerangka kerja yang bertujuan untuk menyediakan suatu kerangka kerja 
yang bermanfaat bagi para profesional dalam rangka mengembangkan literasi informasi.

Selain itu, pedoman literasi informasi IFLA merupakan suatu kerangka sistematika yang dibuat dengan berbagai kontribusi dari para profesional di bidang informasi serta hasil dari diskusi terbuka di Buenos Aires. Pedoman literasi informasi IFLA mencakup konsep literasi informasi dan standar kompetensi internasional yang dapat digunakan untuk mengetahui literasi informasi individu secara umum. Pedoman yang dibuat oleh IFLA dapat diadaptasi dan disesuaikan dengan kebutuhan lembaga yang bersangkutan yang terdiri dari tiga komponen dasar yaitu akses, evaluasi, dan penggunaan sebagai indikator. Responden yang digunakan dalam pemetaan literasi informasi berjumlah 100 orang yang berasal dari Dusun Bulurejo, Sidomulyo, Balekambang dan Dusun Paseban.

Berdasarkan hasilpenelitian dapat disimpulkan bahwa tingkat literasi masyarakat desa Paseban secara umum menunjukkan lebih dari setengah masyarakat $(48,05 \%)$ yang belum memahami literasi informasi baik dari indikator akses, evaluasi maupun penggunaan. Hal ini dapat dilihat pada Tabel 1 berikut.

Tabel 1. Tingkat Literasi Masyarakat Desa Paseban

\begin{tabular}{|l|l|l|l|}
\hline No. & Indikator & Persentase & \multicolumn{1}{c|}{ Keterangan } \\
\hline 1 & Akses & $62,25 \%$ & Sebagian masyarakat memahami akses informasi \\
\hline 2 & Evaluasi & $52,87 \%$ & Sebagian masyarakat melakukan evaluasi informasi \\
\hline 3 & Penggunaan & $40,87 \%$ & $\begin{array}{l}\text { Hampir setengah masyarakat memahami penggunaan } \\
\text { informasi }\end{array}$ \\
\hline \multicolumn{2}{|c|}{ Rata-rata Total } & $51,95 \%$ & \\
\hline
\end{tabular}

Sumber: Olahan Peneliti, 2017

\section{KESIMPULAN}

Program Doktor Mengabdi dengan judul pemetaan literasi informasi masyarakat desa Paseban dilaksanakan dalam rangka memetakan masyarakat desa berdasarkan tiga indicator yaitu akses informasi, evaluasi informasi dan penggunaan informasi. Berdasarkan hasil penelitian menunjukkan bahwa

A. Desa Paseban termasuk dalam kategori desa berkembang dengan nilai IDM sebesar 0,603

B. Tingkat literasi informasi masyarakat desa Paseban masih tergolong sedang, yaitu sebesar $62,25 \%$ masyarakat memahami akses informasi, evaluasi informasi sebesar $52,875 \%$ dan penggunaan informasi adalah sebesar 40,87\%.

C. Potensi Desa paseban cukup beragam mulai dari pertanian, peternakan dan pariwisata.

\section{REFERENSI}

Adam. 2009. Literasi Informasi. Melalui $<$ http://perpus.umy.ac.id/20

09/02/19/literasi- informasi/> pada tanggal 05 Oktober 2015.

Ade Abdul Hak. 2006. Pendidikan Pemakai: Perubahan Perilaku pada Siswa Madrasah dalam Sistem Pembelajaran Berbasis Perpustakaan. Melalui <http://du niaperpustakaan.com/pendidikanpe makai-perubahan-prilaku-padasisw a-madrasah-dalam-sistem-pembela jaran-berbasis-perpustakaan/> pada tanggal 06 Oktober 2015.

Agus Sugiono Pranoto. 2009. Literasi Informasi: Keterampilan Penting di Era Global. Melalui www.library.its.ac.id/news/120/AR TICLE/.../2009-10- 14.html pada tanggal 08 Oktober 2015.

APISI. 2008. Aplikasi Literasi Informasi dalam Kurikulum Nasional (KTSP): 
Contoh Penerapan untuk Tingkat SD, SMP dan SMA. Hasil diskusi Indonesian Workshop on Information Literacy pada bulan Juli 2008. Bogor.

Bambang Kariyawan. (n.d). Pemantapan Jaringan Pembinaan Perpustakaan Nasional terhadap Perpustakaan di Lingkungan Sekolah: Pembudayaan Literasi Informasi di Kalangan Siswa. Melalui <http://www.pnri.go.id/Lis ts/List> pada tanggal 06 Oktober 2015.

Blasius Sudarsono, et al. 2009. Literasi Informasi (Information Literacy): Pengantar untuk Perpustakaan Sekolah. Jakarta: Perpustakaan Nasional RI.

CILIP CSG Information Literacy Group. 2009. Definition of IL. Melalui <http://www.informationli teracy.org.uk/Information_literacy_ definitions/Definitions.aspx $>$ pada tanggal 08 Oktober 2015

CILIP. 2010. Information Literacy: Definition. Melalui <http://www. cilip.org.uk/get-involved/advocacy/ learning/informationliteracy/pages/d efinition.aspx $>$ pada

Depdiknas RI. 2005. Peraturan Menteri Pendidikan Nasional Nomor 25 Tahun 2008 tentang Standar Tenaga Perpustakaan Sekolah/Madrasah. Jakarta: DepartemenPendidikan Nasional RI.

Eisenberg, Michael B., \& Lowe, Carry A. 2004. Information Literacy: Essential Skill for The Information Age (2nd ed.). London: Libraries Unlimited.

Hakim, Sudarnoto Abdul. 2006. PerpustakaanSebagai Center for Learning Society: Gagasan untuk PengembanganPerpustakaan

Madrasah. Jakarta: Fakultas Adab dan Humaniora

Hancock, Vicky E. 1993. Information Literacy for Lifelong Learning.Melalui <2010.http://eric digests.org/1993/lifelong.htm> pada tanggal 08 Oktober 2015.

Jacobs, Melissa E. (n.d). Intergrating Information Literacy in Elementary School.Melalui <http://www.njla.or g/njacrl/usered/mjacobs.ppt> pada tanggal 08 Oktober 2015.

Lakehead University Library 2008.Information Literacy Benefits.Melalui <http://library.lake headu.ca/?pg=728> pada tanggal 08 Oktober 2015.

Lasa Hs. 2007. Manajemen Perpustakaan Sekolah. Yogyakarta: Pinus.

Moekijat.1993. Evaluasi Pelatihan dalam Rangka Meningkatkan Produktivitas. Bandung: Mandar Maju.

Rizal Saiful Haq. 2006. Cakap Informasi: Tanggung Jawab Pustakawan Sekolah dan Pustakawan Guru. Jakarta: Fakultas Adab dan Humaniora UIN Jakarta.

SCONUL (the Society of College, National and University Libraries. BRIEFING PAPER Information skills in higher education Prepared by the SCONUL Advisory Committee on Information Literacy. October 1999. Diakses melalui (https://www.sconul.ac.uk/sites/defa ult/files/documents/Seven_pillars2.p df) pada tanggal 15 Juni 2017 pukul 12.39 WIB.

Suherman. (n.d). Literasi Informasi: Kunci Kemajuan yang Terbuang. Melalui <http://www.bit.lipi.go.id/ masyarakat-literasi/indexphp/lite rasi-kunci-kemajuanyangterbuang> pada tanggal 09 Oktober 2015.

Sulistyo-Basuki. Literasi Informasi dan Literasi Digital. Diakses melalui (https://sulistyobasuki.wordpress.co $\mathrm{m} / 2013 / 03 / 25 /$ literasi-informasidan-literasi-digital/) pada tanggal 15 Juni 2017 pukul 12.07 WIB.

Thompson, John Taylor. 1995. Writing the Narrative-Style Research Report in Elementary School. Childhood 
Education Vol. 71. Melalui:

xxg1GjqmsSPQQSjxnRyXsx!20247

<http://www.questia.com/

$63545 ! 459975982 ?$ docId $=50022258$

googleScholar.qst;jsessionid=LGGV

87> pada tanggal 08 Oktober 2015

Mb9LS145Prbh7nY42K1HQkt5Kc 